\title{
THE PROBLEM OF CHOICE IN PAULO COELHO'S ELEVEN MINUTES AND BRIDA: A LESSON TO OWN UP TO YOUR DECISIONS AND ACCEPT WHO YOU ARE
}

\author{
MARINA JOYCE ROCHE ${ }^{1} \&$ DR. R. JAYAKANTH ${ }^{2}$
}

${ }^{1}$ Research Scholar, Department of English, St. Joseph's College, Trichy, Tamil Nadu, India

${ }^{2}$ Assistant Professor \& Research Supervisor, Department of English, St. Joseph's College, Trichy, Tamil Nadu, India

\begin{abstract}
"Life always waits for some crisis to occur before revealing itself at its most brilliant."

- Paulo Coelho, Eleven Minutes

Freedom to choose is what makes us unique. Existentialists believe that humans do not have a structured behavior pattern; everyone creates their identity through choices. Making the right choice in everyone's life constitutes a vital life skill. We are always startled to pick what we want hence the conflict between what we want, what we need, and what we have. We, humans, are exposed to numerous circumstances, and therefore the problem of choice puts us in the spotlight. We are judged based on our decisions and voluntary actions. Freedom of choice, according to existentialists, is humanity's primary distinction. We encounter every day the problem of picking the right path or making the right choice. Choices come along in our day-to-day life and begin to create our aura or personality based on our preferences. Thus, creating our own lifestyle or value system. The novels Brida and Eleven Minutes explore the twists and turns that the protagonists take while they choose their path in search of knowledge and happiness, respectively. As the novels unfold, we learn that all the choices we make are never meant to break us. It is in unlearning we also learn to rebuild or recreate ourselves and find meaning in our existence. Therefore, this paper attempts to understand how people need not end up negatively when they make any bad decisions.
\end{abstract}

KEYWORDS: Existentialism, Choices, Resonate, Venture, Humanity \& Identity

Received: Aug 07, 2021; Accepted: Aug 27, 2021; Published: Sep 16, 2021; Paper Id.: IJELDEC202112

\section{INTRODUCTION}

The choices that we make have a significant impact onus. These choices often do not have a specific nature. It is difficult to judge because individuals are free to choose their path, accept risk, and follow their intuitions to commit to something or someone or even succumb to the situation. Like many existentialists, Jean-Paul Sartre thought human beings live in constant conflict of choosing between different paths. We become aware of ourselves and have to make choices. Even deciding not to choose is a choice. According to Sartre, every choice reveals what we think a human being should be. We are doomed to the task of creating ourselves, no matter how limited the options are, and there is no possibility of opting out.

Eleven Minutes is a story of a young,ambitious girl Maria who dreams of being a queen in someone's life and desires a bright, comfortable future, which leads her to Switzerland as a Brazilian Samba dancer and thena prostitute. Mariaexperiences pleasure and pain, love and rejection.With every experience, she thrives on changing the direction of her life to make it better and acceptable. Maria grows up in a small town with small joys of life. In 
her teenage, her goal was to fall in love and be an example to the other girls in her circle. As she grew older, her dream further extends to marrying someone rich and handsome and settling to be a homemaker taking care of her children, and so forth. Still, after several failed relationships, she decides that she is destined to live alone as most people aren't trustworthy. Maria holds a very diverse approach to life different than the people from her town. Her views about life pushes her as an explorer, and she becomes an adventurous woman in Switzerland. However, her world of fantasy comes crashing when she encounters harsh realities. Maria leaves the club for a better prospect with a good amount of severance, hoping she could manage her livelihood for a few weeks, but without finding a career of her choice, she becomes a prostitute. Over time, Maria falls in love with a painter, Ralf.With him, her search for a soulmate ends. Ralf's intervention in Maria's life teaches her to find meaning in everything she does, Ralf teaches her to trust the process of life, and this attitude brings them together and accept each other's flaws and strengths and inspire each other.

As the existentialist Sartre points out, the greatest struggle one faces is being condemned to be free.He says human beings always live in anguish not because life is challenging, but because of the various situations we are thrown into and expected to choose based on the best available options. Many of us choose to be silent or do not react or respond. Sartre says not deciding also becomes a kind of choice on its own.

All of our choices reveal our personalities and deep desires. InMaria's case, one could conclude that she made some tough choices in life,and ultimately,they led her to fulfill her dreams. She becomes aware of her being and experiences true love in the company of Ralf.

The search for love and a comfortable life brings her to Rio de Janeiro. She meets a swiss man who offers her a job as a Samba dancer in a nightclub in Geneva. From Maria's Diary

"Everything tells me that I am about to make a wrong decision, but making mistakes is just part of life. What does the world want of me? Does it want me to take no risks, to go back to where I came from because I didn't have the courage to say "yes" to life?"

I made my first mistake when I was Eleven years old, when that boy asked me if I could lend him a pencil, since then, I've realized that sometimes you get the second chance and that it's best to accept the gifts the world offers you. Of course, it's risky, but is the risk any greater than the chance of the bus that took forty-eight hours to bring me here having an accident if I must be faithful to someone or something, then I have, first of all, to be faithful to myself, If I'm looking for true love, I first have to get the mediocre loves out of my system. This little experience of life, I've had has taught me that no one owns anything, that everything is an illusion-and that applies to material as well as spiritual things. Anyone who has lost something they thought was theirs forever (as has happened often enough to me already) finally comes to realize that nothing really belongs to them.

And if nothing belong to me, then there's no point wasting my time looking after things that aren'tmine; it's best to live as if today were the first(or last) day of my life. (page 25-26)

I can choose either to be a victim of the world or an adventurer in search of treasure. It's all a question of how I view my life. (page-39)

Sartre states,"We do not know what we want and yet we are responsible for what we are — that is the fact." These quotes from Maria's dairy tell us that she is aware of her being,she is conscious of the decisions she will take, and she is prepared to face the conflicts. Her concerns over human vanity, conflicts, and fears about the decisions taken out of 
frustration, show us how fragile we are as humans.

I am here because I chose this fate. The roller coaster is my life; life is fast, dizzingling game, life is a parachute jump; it's taking chances, falling over and getting up again; it's mountaineering; it's wanting to get to the very top of yourself and to feel angry and dissatisfied when you don't manage it. (page -49)

People talk as if they know everything, but if you dare to ask a question, they don't know anything (page - 59)

I let fate choose which route I should take now, and then her thought takes the path of love and happiness, which constitutes an essential need of human existence.

Honour, Diginity Self respect. Although, when I think about it, I've never had any of those things, I didn't ask to be born, I've never found anyone to love Iv always made the wrong decisions- now I'm letting life decide for me.(Page-64)

Now Maria takes up her profession as a challenge, and she devotes herself to learning everything about giving pleasure to her client who comes to Copacabana in search of happiness.Maria is a mother to those who seek advice, a compassionate friend to those who share their struggles, and an ordinary prostitute to those who come there for physical gratification. She reads books, magazines, and newspapers to keep herself up to date. She wasn't a victim of fate. She was taking risks, pushing herself beyond her limits, experiencing things which, one day, in the silence of her heart, in the monotony of old age, she would remember almost with nostalgia- however absurd that might seem. She was fighting for herself. She always took courage in expressing what she wanted to get out of her own choices. She started visiting the library, reading self-help books, learning about marital problems, psychology, and politics to keep her clients happy. Her visit to the library and short conversations with the librarian made her feel good that she has someone in an unknown city to call as a friend, a confidant with whom she loved to spend time and listen to. Their conversations always gave a better perspective on Maria's life. Those conversations made her complicated thoughts simple.

Being in Copacabana and being a prostitute was Maria's survival skill. As the days pass by in Copacabana and her mundane life as a prostitute, she concludes that some people are born to face life alone. She chooses this because she had nothing to lose. Though she loves to try new ways, she never regrets any of her decisions. She always looks for opportunities to learn something new, which kept her going. Paulo Coelho created Maria to appeal to so many of us who give up on life when faced with minor challenges in life. Maria stands as the epitome of resilience.

\section{Maria and her Thoughts on Love}

The usual feelings made maria reflect on her choices and she writes - Today, I realized why this was happening; its been such a long time since I thought about love or anything called love. It seems to be running away from me as if it wasn't important anymore and didn't feel welcome. But if I don't think about love, I will be nothing. I need to write about love. I need to think and think and write about love-otherwise, my soul won't survive.

In love, no one can harm anyone else; we are each of us responsible for our own feelings and cannot blame someone else for what we feel. That is the true experience of freedom: having the most important thing in the world without owning it.

The only thing that can change one's life is love. One fine day destiny brings her to Ralf Hart,a painter and love of her life. It's with him she learns and unlearns lessons of life. It'swith him she feels loved and respected. It is in his company she feels comforted. This encounter with Ralf gives her new hope and wings to her dreams. Ralf is the one who recognizes 
theremarkable light in Maria, and from then on, her life takes a turn for the positive.She tries to find meaning in everything she does. There is the hope of a new life with Ralf. A choice of saying yes for the painting, to staying a little longer to have coffee andsharing life's most profound questions with a stranger completely transports her to a new world of expectations and love. She gets attracted to Ralf's personality, not because he was successful in life or had made enough money, but because someone looked at her for the first time in her life not as an object, not even as a woman, but as something she could not even comprehend.For the first time, she felt that someone is seeing through her soul, trying to read her inner self. Someone who would accept and adore her for what she is and not what she was. Some stranger has seen something special which she was not aware herself. Maria spoke her heart out for the first time. She was sharing her life, her thoughts, and her venture. However,Maria was upset that Ralf discovered that she was a prostitute. Ralf says the light in her is the light of willpower, one's confidence and courage to face life, and the sacrifices she has made to reach where she is today.

"I can choose either to be a victim of the world or an adventurer in search of treasure. It's all a question of how I view my life." (Page 39)

Maria chose to be an adventurous woman and decided to take life as it comes. She treated every event as a new experience to enrich her knowledge. She stopped cursing herself and decided to enjoy and take life as it comes and live like every day was fresh and the first or the last day of her life. Though boredom and sadness shook her confidence at times, she pulled herself through it all with the hope of love and faith. Several times she revisits the decision of returning to her country. Still, the fear of failure and facing her friends and people's comments around her was so intense that she believed staying and facing life's challenges was a better option for her.

"I am no longer sure of anything. If I satiate my desires, I sin, but I deliver myself from them; if I refuse to satisfy them, they infect the whole soul."This statement of Jean Paul Sartre is so real in Maria's life when she writes in her diary.

I am here because I chose this fate. The roller coaster in my life: life is fast, dizzying game: life is a parachute jump; it's taking chances, falling over and getting up again; it's mountaineering; it's wanting to get to the very top of yourself and to feel angry and dissatisfied when you don't manage it. (page 49)

Dreams like theirs never lasted long, and Maria had enough life experience to know that reality usually chose not to fit in with her goals. And that was now her great joy: to say to reality that she didn't need it, that she was no longer dependent on what happened her to be happy. (page-137)

In Sartre's famous phrase, "existence precedes essence." There is only the absurdity of arriving in a world with no plan, God, universal codes, or fixed standards of value: just a dizzying array of decisions to make. And yet, rather than making life trivial, the absurd condition described by Sartre lends substantial weight to all of our choices, for in making them, he claimed, we are not only creating ourselves but deciding what a human being should be.

Maria's relationship with Ralf teaches her the ability to derive pleasure through pain. This helps her to recognize her bright and dark days - the symbolism of her weaknesses and strengths. These delicate threads of the known and unknown make her aware of the choices that she's made and leads her to a more gratifying life.

Sylvia Path says, "I want to taste the glory in each day and never be afraid to experience pain," a statement that especially rings true in Brida's narrative. 
Paulo Coelho's narration creates Brida. In this novel, Brida, a young girl who aspires to be a magician, visits Magus and Wicca. The two teachersfollowed the tradition of the Sun and the Moon, respectively.They help Brida pursue her dream; however, it was not easy to choose as Brida goes through many internal conflicts to choose her path. For Brida, it was not just the picking of her approach to conquering her dream but also learning to know her true love/ soulmate that becomes a real challenge. Magus, who recognizes Brida as his soulmate in the first meeting, never reveals to her that she is his long-awaited soulmate until Brida herself can see the light in Magus. In the process, her search for a soulmategrows stranger, and she conflicts with choosing the love of her life and the soulmate of her dreams. This was the same question that Magus poses her when she meets him for the first time.

Nevertheless, Brida pursues her passion and fulfills all the requirements to be initiated as a witch through a ceremony. It was just before this ceremony when Brida was in a great dilemma as she had recognized both Lorens and Magus as her soulmate and could notmake a decision.Her mother then shares an intimate secret of life. For love,distance, creed, and time are never constraints. If you are passionate enough, the moment you have spent with someone who has touched your soul becomes part of your being.Though the person leaves you, the light they have lit in you remains with you forever, thus giving you strength every time you seek love. Love that conquers everything and lives with you forever despite the distances.Through this story, Brida learns the most significant lessons of her life - love and sacrifice. In the end, her mother's advice helps herchoose the love of Lorens over her soulmate Magus. Though Maria recognizes both of them as her soulmate she chooses Lorens and Magus remains as her dream with whom she once connected with for soul experience.It wasn't so much a question, it was a choice, the most difficult choice anyone would have to make in life. It was something she had already thought a lot.

This question creates a lot of distress in her.Little did she know that this question will become the question of her existence. Life constantlypresents us with choices, and the choices that we make shapes our lives. Some options are without conflicts, and some create confusion. We often give upin such circumstances. Brida accepts the risk and looks forward to the great experiences and lessons to become what she wanted to. In Lorens, she finds a friend with similar interests whom she can rely on, talk her heart out, and listen to his stories. Lorens always encouraged her to achieve her heart's desires. On the other hand, in Magus, she sees a strong man who motivated and inspired her, and it is in his company she was full of life and was zealous to reach the pinnacle of success and happiness. Both Lorens and Magus were special to Brida, and it was hard for her to choose.

By risking failure, disappointment, disillusion, but never ceasing in your search for love. As long as you keep looking, you will triumph in the end.(Page-39)

She wasn't afraid of difficulties; what frightened her was being forced to choose one particular path. Choosing a path meant having to miss out on others. She had a whole life, and she always thought that in the future, she might regret the choices she made now(Page-97)

Brida was ready to take the risk and face challenges to become what her heart desired.Her introspection and reflections pushed her towards her destiny. Brida questioned everything around her and kept filling herself with knowledge and wisdom.This approach turned out to be her key to successfully being initiated to witchcraft. Her father's advice was still fresh as she reflects on the choices and the decisions to choose a path. Brida remembers her father once said even a stopped clock is right twice a day. I must take the risk, face fears, have faith. These are the few affirmative phrases that Brida often repeats in a crisis, and she holds on to these for strength. 
"Everything has been figured out, except how to live." One ofSartre's often quoted statement about life and its twits and turns, destructions and constructions when one is unable to take responsibility we claim it to fate. Here Colhe's protagonist Brida too goes through the same situation and declaresSometimes, certain of God's blessings arrive by shattering all the windows -(Page 104)

Both Maria and Brida desire a life of love and companionship. They allow destiny to control parts of their lives. Through challenges and failures, they learned that life is worthy with its ups and downs. We do make mistakes, but the lessons that we learn from our mistakes direct our future path. Trusting oneself and the processes of life is all that it takes for us to reach our destiny. Paulo Coelho uses light as a medium to recognize true love in both novels. In Eleven Minutes, Ralf sees a bright inner light in Maria thatattracts him towards her, and in Brida, it was Maguswho sees the light. Both these characters trust the process of fate.

In his novels Eleven Minutes and Brida, Paulo Coelho gives the essence of existential perspective, especially the problem of choice.Both Brida and Maria face challenges in life, but they do not give up. They trust the process of life and believe that life has so much to offer as it progresses. It is this trust and faith in destiny which makes them unique. Each of the characters in Paulo Coelho's novels enjoys the freedom of choice no matter what. They act according to the situation, and it might look to the readers that their choices may not be correct. Still, eventually, the readers feel one with the characters. It appeals to the readers that every choice the characters make in their lives need not necessarily be a wrong one.

Making no choice is also a choice.Choosing between right and wrong, good and evil, is part of every individual's life. It is the author's perspective and his experiences that make these characters unique. His short but profound statements transport the reader to walk the path alongside his protagonists. This is especially true in both his narratives - Eleven Minutes and Brida. Both Maria and Brida, the protagonists of the novels, accept risks and make difficult choices. These are quintessential examples of Paulo Coelho's style. They trust the process of life and never give up on their dreams nor lament their chosen path to achieve their goals.

Humans, by nature, are good and born with decision-making abilities. This quality leads them to meaningful relationships and creates interest in themselves and others. We lean towards therapeutic relationships, which boost our confidence and fill us with positivity. In Maria's life, it was Ralf and Brida always ran to Magus to rejuvenate, to learn and to see events of life with a perspective. We are not the victim of our circumstances but rather a product of our decisions in our lives. It is human to blame destiny without even realizing that our choices lead us to where we are. With these novels, one can conclude that life is like a roller coaster ride,and the choices we make, the decisions we takecontrols this ride and takes the path based on the choices. We as humans should trust ourselves and the process to lead us to a better tomorrow.

\section{REFERENCES}

1. Chand, Gian \& Chandel, N. (2019). Sex, Desire and Subjectivity in Paulo Coelho's Eleven Minutes.

2. Shanlax International Journal of English. 7. 25-31. 10.34293/english.v7i4.584.

3. Coelho, Paulo (2003). Eleven Minutes:HarperCollins Publishers Inc.

4. Coelho, Paulo. (2008). Brida: HarperCollins Publishers Inc.

5. http://eprints.ums.ac.id/28251/14/PUBLICATION_ARTICLE.pdf 
6. $\quad$ http://etheses.uin-malang.ac.id/3017/1/11320107.pdf

7. http://jimbastrafib.studentjournal.ub.ac.id/index.php/jimbastrafib/article/view/100

8. $\quad$ https://www.flavorwire.com/463783/30-jean-paul-sartre-quotes-for-your-next-existential-crisis

9. $\quad$ https://www.ncbi.nlm.nih.gov/books/NBK64939/

10. https://yourstory.com/2018/02/why-and-how-of-market-validation/amp? utm pageloadtype $=$ scroll

11. https://www.researchgate.net/profile/Vijay-More-

5/publication/310263978 Existential Attribute of Choice in Paulo Coelho's The Alchemist/links/582ae34f08ae004f74af19 71/Existential-Attribute-of-Choice-in-Paulo-Coelhos-The-Alchemist.pdf

12. https://www.jstor.org/stable/20343243

13. https://polylogos-journal.ru/s258770110010030-5-1/?sl=en

14. http://etheses.uin-malang.ac.id/3017/

15. https://jurnalmahasiswa.unesa.ac.id/index.php/index/index

16. "Jean-Paul Sartre Quotes." BrainyQuote.com. BrainyMedia Inc, $2021 . \quad 1 \quad$ September 2021. https://www.brainyquote.com/quotes/jeanpaul_sartre_103662

17. Pandya, Digvijay, and Aarti Mahajan. "Jean Sasson: An Existential Perspective of Middle East." International Journal of English and Literature (IJEL) 8 (2018): 63-68.

18. Abulmaaty, Atif A. "Alienation in Leila Aboulela's the Translator." International Journal of English and Literature (IJEL) 6 (2016): 37-46.

19. Singh, Archana. "Quest for Identity and Dilemma of Women in Nayantara Sahgal's Storm in Chandigarh and Anita Nair's Ladies Coupe'." International Journal of English and Literature (IJEL) ISSN (P) (2016): 2249-6912.

20. Gairola, Ishan. "Depiction of Existential Anxiety in Harold Pinter's The Room." International Journal of Linguistics and Literature (IJLL) 6 (2017): 15-18. 
